\title{
THE INFLUENCE OF PROFIT SHARING, TRADE FINANCING, AND THE NON PERFORMING FINANCING RATIO TO THE RETURN ON ASSET OF ISLAMIC RURAL BANKS IN CENTRAL JAVA (2013-2015 PERIOD)
}

\author{
Nur Hayati ${ }^{1 *}$, Umiyati $^{2}$, and Ilhamdi ${ }^{3}$ \\ ${ }^{1}$ Depok Islamic Economy Academy, Indonesia
}

\begin{abstract}
This study examines how profit-loss sharing (PLS) and trade financing as well as non performing financing (NPF) can affect the Return on Asset (ROA ) of Islamic Rural Banks in Cental Java (Period of 2013-2015). The sample selection method used is the purposive sampling. The data analysis method used a multiple regression dated panel with a significance level of 5\% (0.05). The result of the data analysis showed that the suitable model used in this study is the Common Effect Model (CEM). Simultaneous independent variables significantly influence ROA. The partial, variable of PLS has negative effect on the ROA of Islamic Rural Banks, while trade financing dan NPF did not have a significant effect on the ROA of Islamic Rural Banks.
\end{abstract}

Keywords: Non Performing Financing (NPF), Profit-Loss Sharing Financing, Return On Asset (ROA), Trade Financing

\section{INTRODUCTION}

The growth of syariah banking in Indonesia continues to experience development. Government support and a positive welcome from the Indonesian society made syariah banks as the Syariah Financing Institution that is proven to stand in the economic crisis condition. Islamic Rural Banks became one of the Syariah Financing Institutions which is potent in the development of syariah banking today.

According to Act No. 21 year 2008 Islamic Rural Banks are Syariah Banks whose activities do not provide service the payment traffic.

Islamic rural banks have a specific goal, which is to provide service and banking products to the economically weak society and small businesses in the city and the rural areas. The small business market potential which banks can penetrate is large enough, because there are still many performers of small businesses which are not yet reached by syariah banks, in the capital specifically.

The Islamic Rural Bank Fund distribution consists of trade financing (Murabahah, Salam, Ishtishna). profit sharing financing (Musyarakah and Mudharabah), lease financing (Ijarah IMBT) and Qardh financing. Yet the distributions that lslamic Rural Banks mostly use are the murabahah financing (MRBH), mudharabah financing (MDRBH) and the musyarakah financing (MSA). The primary income of Islamic Rural Banks is from the markup/margin

* Corresponding author. Email address: nhayadhana@gmail.com 
from the murabahah financing pact and the profit sharing income which is obtained from the mudharabah and musyarakah financing pacts. The benefit obtained from the murabahah (mark up/margin murabahah) is deterimined by the deal in the pact by Islamic Rural Banks with the customers and the income characteristic which is definitely recognized for the benefit value.

Meanwhile the profit from the mudharabah and musyarakah financing activities is a nisbah profit sharing which is agreed in the contract by the Islamic Rural Bank and the customer with the profit sharing value undetermined because this contract is an investment contract. An investment contract means that profit or loss is very much possible in the contract period so it is stated that the mudharabah and musyarakah is more risky than the murabahah financing. Because of that, Islamic Rural Banks need to be active in anticipating the financing loss of profit sharing since early in the fund distribution.

The Islamic Rural Bank profitablility is not only as a cause of fund distribution or financing. Another factor which influences is the risk of fund distribution, which is bad credit or a Non Performing Financing increase. for making the Provison for Impairment Losses to increase so it causes a decrease in capital, rentability or profitability and the syariah banking efficency (Financial Services Authority, 2016, p.34).

The research of Yulianto (2014) with a case study of Syariah Public Banks in Indonesia stated that profit sharing financing has a negative influence while trade financing and NPF does not influence profitablity. In contrary with the research result of Rochmatika (2014) where NPF has a positive influence to profitability and trade financing has a negative influence to profitability. While in the research of Hidayati (2013) the result showed that NPF and mudharabah has a positive influence to BMI profitability and musyarakah financing has a negative influence to profitability.

The difference of previous research results were related with which variable influences profitability in Syariah Public Banks. The researcher selected Islamic Rural Banks as the research object because Islamic Rural Banks are present as the syariah banks that directly interacts with the lower middle income society (serving banking needs of small businesses in cities and rural areas) which is expected to raise the Indonesian economy. The small business activities are mostly done by the Indonesian people, which need support from financial institutions for the financing.

\section{FRAMEWORK AND HYPOTHESIS FORMULATION Syariah Financing Public Banks}

Based on the Republic of Indonesia Act No. 21 year 2008 about Syariah Banking it is stated that Islamic Rural Banks are Syariah Banks which in their activities do not provide service in payment traffic. The goals of establishing Islamic Rural Banks are as the following (Sudarsono, 2012):

a. To increase the economic welfare of Muslims, especially the lower income society which are generally in the rural areas

b. To increase jobs especially in the district level so it can decrease the urbanization flow.

c. To maintain the spirit of ukhuwah islamiyah through economic activities in the frame of increasing per capita income to an ideal life quality.

According to BI Regulation No.6/17/PBI/2004 the business activities of Islamic Rural Banks covers: 
a. Collecting funds from society in the forms of:

1) Savings based on the wadhiah and Mudharabah principles

2) Long term deposits based on the Mudharabah principle

3) Other forms that use the wadhiah and Mudharabah principles

b. Distribute funds to society in the forms of:

1) Trade transactions based on the principles of Murabahah, Ishtishna and/or Salam.

2) Leasing transactions with the Ijarah principle.

3) Profit sharing financing based on the principles of Mudharabah and/or Musyarakah.

4) Financing based on the Qard principle.

c. Doing other activities which are not contradictory with banking acts and the Syariah principle.

According to the Act No. 21 Article year 2008 Islamic Rural Banks have a prohibition for doing the following activities:

a. Doing business activites which are prohibited by the syariah principle.

b. Accepting savings in the form of accounts and participate in the payment traffic.

c. Doing business in foreign currency, except foreign currency exchange with the permission of Bank Indonesia.

d. Doing insurance business, except as agents of marketing syariah insurance products.

e. Doing capital inclusion, except in institutions that are formed for overcoming the liquidation difficulty of Islamic Rural Banks; and

f. Doing other activities outside of the business activities as intended in Act No. 21.

\section{Factors that influence \\ Profitability of Profit Sharing Financing}

According to the Islamic commerce law, a partnership and all forms of business organizations are established with one goal, which is profit sharing through common participation. Mudharabah and Musyarakah are financing capitals of profit sharing which are suitable for the goal. Mudharabah is a contract between two parties, which are the first party as the capital owner (shahibul mal) and the second party as the fund manager (mudharib) for managing a business by an agreement of the nisbah profit sharing of the obtained profit, while the loss that occurs is the risk of the fund owner as long as it is not proven that the mudharib is cheating or performing a misconduct. (Wardiah, 2013).

While a Musyarakah is a cooperation pact between two or more parties for a certain business where each party provides a fund contribution (competence, expertise) with the agreement that the profit and risks will be taken responsible together according to the agreement (Djuwaini D., 2007)

\section{Trade Financing}

Murabahah is a trade contract between two parties and both agree on the selling price which consists of the buying price added by the buying fare and a profit for the seller. The forms of Murabahah can be done in cash or by paying in installments. (Wardiah, 2013). In the Murabahah transaction banks do not take responsibility of profit and loss such as in the profit sharing financing 
(Mudharabah and Musyarakah) the Mark-up or margin is different from interest because in the markup/margin it is not explicitly connected with financing time but based on the transaction for the service provided or also known as commodity trading. (Djuwaini, 2007, p.60).

\section{Non Performing Financing Ratio (NPF)}

Non performing financing is bad credit which consists of substandard, doubtful, and loss classifications. When associated with the NPF ratio, this Non Performing Financing category is the financing in the 3,4, and 5 collectabilities (Ilham, 2016, p.5). Bad credit or problematic financing are categorized as productive assets where the collectability is doubted. For maintaining the $D P K$ safety, syariah banks are obliged to form a reserve of the problematic financing. The more the funds are reserved, the more funds that will be taken responsible for the problematic financing reserve. The problematic financing reserve is obtained from company profit and this influences the profitability of the bank (Financial Services Authority, 2016).

The NPF is known by counting the substandard financing to the total financing. If the NPF is low, the profit is high. If the NPF is high, the bank will experience loss caused by the return level of bad credit. The equation is illustrated as the following:

$$
N P F=\frac{\text { Substandard Financing }}{\text { Total Financing }}
$$

Source: Suprapto (2015)

\section{Return on Assets (ROA) Ratio}

Return on Assets or ROA is a form of profitability ratio for measuring company ability in producing profit by using the total assets that are present after the capital costs (costs which are used to fund assets) which is known from the analysis (Ilham, 2016). ROA is chosen as an indicator of measuring bank financial performance because it measures company effectiveness in producing profit by using the assets owned. ROA assists companies which already implement accounting well for measuring the efficiency of capital use as a whole, which is sensitive to all matters that influence a company's situation so the company's position to the industry can be known. This is a step in strategy planning (Suprapto, 2015) ROA is formulated in the following picture.

$$
R O A=\frac{\text { Profit Before Tax }}{\text { Total Assets }}
$$

Source: Suprapto (2015)

A positive ROA shows that the total assets used in the company's operational activities are able to provide profit or an advantage for the company. While a negative ROA shows the total assets used in the operational activities do not provide profit or causes a loss to the company. (Ilham, 2016).

\section{Hypothesis}

\section{Influence of Profit sharing Financing to ROA}

Profit sharing financing is an asset forming component in Islamic Rural Banks. The profit sharing financing consists of the Mudharabah and 
Musyarakah pacts. The profit sharing financing is a financing that is based on the profit and loss sharing (PLS) principle. So Islamic Rural Banks obtain incocome from profit sharing financing activities in corresponding with the agreed nisbah with the customers. The income obtained influences the profit size that Islamic Rural Banks obtain with the profit sharing, mudharabah and musyarakah financing.

\section{Influence of Trade Financing to ROA}

Murabahah is an alternative capital of the funding activity that syariah banks implement. Murabahah is an Islamic investment that is not based on the profit and loss sharing (PLS) principle. In the investment activity, murabahah distances the present uncertaitnity in incomes from businesses with the PLS system, because the Murabahah principle is tha the cost plus is recognized as the income. The additional income of this cost can be named as the murabahah mark up/margin.

The fund distribution in the Murabahah financing is one of the largest asset forming components in Syariah Financial Institutions that produces income in the form of margins/mark ups. The obtained income of the mark up/margin will influence the profit size obtained. And in the end it is able to influence the profitability increase which is reflected from the ROA (Return on Asset).

\section{Influence of Non Performing Fiancing Ratio to ROA}

Non performing financing is a ratio that is used for measuring the management ability of the bank in managing the present probelmatic financing, it can be fulfilled by the productive assets that a bank has. The problematic financing that grows can eventually influence the probability of a reduction of profit/income that a bank obtains. Because in the problematic fund financing reserve or NPF this is considered as a cost where the percentage is taken directly from the operational profit or income of the bank. Islamic Rural Banks have a function as an intermediate institution like banks. For that this statement can be applied in Islamic Rural Banks.

\section{Influence of Independent Variable Simultants to Dependent Variables}

The last test is a test of independent variables that are present simultaneously or together, whether they have a significant influence to the profitability of Islamic Rural Banks of Central Java in the 2013-2015 period.

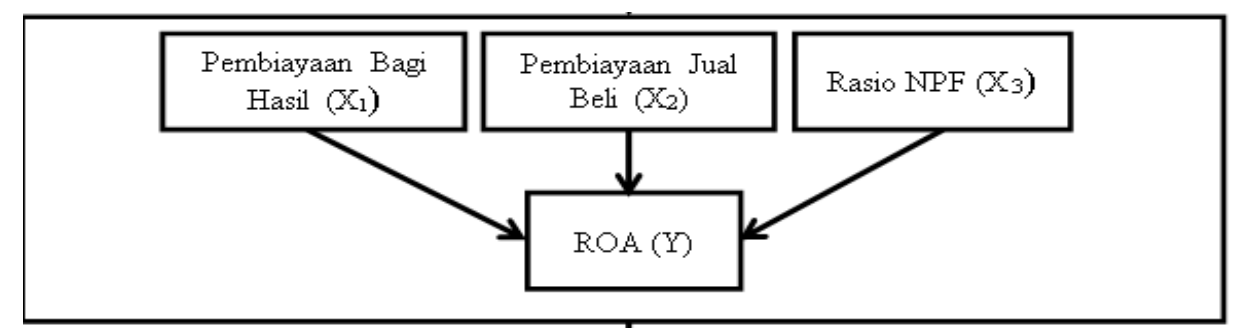

A hypothesis is a statement that states the expected relation logically between two variables or more in a formulatic proportion which can be tested empirically. The hypothesis in the qualitative research is developed from theoretical research so the temporary answers from the problem or statement needs to be tested empirically.

The hypotheses which can be proposed in this research are: 
$\mathrm{H}_{01}$ : the profit sharing financing variable, trade financing and NPF does not influence partially to the ROA of Islamic Rural Banks in Central Java in the 2013-2015 period.

$\mathrm{H}_{\mathrm{a} 1}$ : the profit sharing financing variable, trade financing and NPF influences partially to the ROA of Islamic Rural Banks in Central Java in the 2013-2015 period.

$\mathrm{H}_{\mathrm{a} 2}$ : the profit sharing financing variable, trade financing and NPF does not influence simultaneously to the ROA of Islamic Rural Banks in Central Java in the 2013-2015 period.

$\mathrm{H}_{\mathrm{a} 3}$ : the profit sharing financing variable, trade financing and NPF influences simultaneously to the ROA of Islamic Rural Banks in Central Java in the 2013-2015 period.

\section{RESEARCH METHOD}

The method used in this research is the qualitative method which has a goal to obtain the result from data processing in the form of numbers and analyzed using statistics (Sugiyono, 2016). The research type is the associative because it observes the relation of variables to the research object and is causal in character, so in the research there are independent and dependent variables. From those variables, it is then searched about how is the financing influence of the independent variables to the dependent variables (Sugiyono, 2016).

The variables used in this research consists of three independent variables which are profit sharing financing, trade financing, Non Performing Financing (NPF) Ratio; and one dependent variable which is the Return on Asset (ROA). This research is implemented to seek the influence of the independent variables to the dependent variable.

\section{Data Types and Source}

The data type used is the secondary data, in the form of a three-month financial report of Islamic Rural Banks in Central Java from 2013-2015. Sourced from the official site of the Financial Services Authority (OJK) www.ojk.go.id. The data gathering technique used in this research is the documentation method, which is by gathering Islamic Rural Bank three-month financial reports in Central Java which were obtained from the official Financial Services Authority $(O J K)$ www.ojk.go.id.

\section{Population and Sample}

The population in this research are the Islamic Rural Banks in Central Java which total at 26. The sample gathering technique in this research is the purposive sampling. Based on the purposive sampling the total Islamic Rural Banks that are samples in this research are as the following:

Table 1 Research Samples and Objects

\begin{tabular}{|lc|}
\hline Criteria which is the consideration in determining samples & Total \\
\hline Islamic Rural Banks in Central Java Province & 26 \\
\hline $\begin{array}{l}\text { Islamic Rural Banks in Central Java that publish the three-month financial } \\
\text { report for the research period which is in the quarter 1 2013 until quarter 4 }\end{array}$ & 21 \\
\hline 2015 & 21 \\
\hline Islamic Rural Banks in Central Java which have data comprehensiveness & 7 \\
\hline Islamic Rural Banks in Central Java that have total assets more than 20 billion & 12 \\
\hline Total Periods Studied (three-month period in 2013-2015) & $7 \mathrm{x} 12=84$ \\
\hline Total Research Data &
\end{tabular}

Source: Processed Data (2016) 
Based on the purposive sampling result, seven Islamic Rural Banks are obtained which are Islamic Rural Bank Buana Mitra Perwira, Islamic Rural Bank Artha Surya Barokah, Islamic Rural Bank Suriyah, Islamic Rural Bank Sukowati Sragen, Islamic Rural Bank Gunung Slamet, Islamic Rural Bank Insan Madani, and Islamic Rural Bank Bina Amanah Satria.

\section{Data Analysis Technique}

This research uses the data panel regression analysis method processed using the Eviews 9 program. The goal is for finding the profit sharing financing influence $\left(\mathrm{X}_{1}\right)$, trade financing $\left(\mathrm{X}_{2}\right)$ and $\mathrm{NPF}$ ratio $\left(\mathrm{X}_{3}\right)$ to ROA (Return on Asset). Yet before the data panel regression analysis is done, the Stationarity Test and Classic Assumption Test is previously done.

\section{Stationarity Test}

A data is said to be stationary if the average error value and variant value of the variable is constant for the time. The stationarity test is importantly done to know if there is a breach in the regression assumption. The primary problem that occurs is that the data used in the regression analysis is not stationary, the estimated value result becomes biased (spurious regression), so it causes mistakes in the analysis result interpretation (Winarno, 2011).

There are several methods of the stationarity test in the data panel, among them is the unit root test. As for the method used for examining the unit root test in this research is by usingthe Augmented Dickey-Fuller (ADF).

\section{Classic Assumption Test}

A model is said to be suitable for a predicting instrument if it has the best non- linear characteristics of an interpreter. Other than that a model is said to be suitable enough and can be used to predict if it passes the series of classic assumption tests that underlies.

The classic assumption test is used to ensure that the regression model already fulfills the basic assumption so it can be used for testing the hypothesis. The classic assumption test needs to be implemented because in the regression model there needs to be attention to the presence of deviations of the classic assumption. Because basically, if the classic assumption test is not fulfilled, the explaining variables become inefficient (Setiawan, 2015), The classic assumption test consists of:
a. Normality Test
b. Multicolinearity Test
c. Heteroscedascity Test
d. Autocorrelation Test

\section{Double Regression Linear Test}

The regression analysis is needed for finding the independent variable influence in influencing dependent variables partially and simultaneously.

The Data Panel Regrsion Equation in this research:

$$
\text { In Yit }=\beta 0+\beta 1 \operatorname{In} X i+\beta 2 \operatorname{In} X 2+\beta 3 \operatorname{In} X 3+e i t
$$

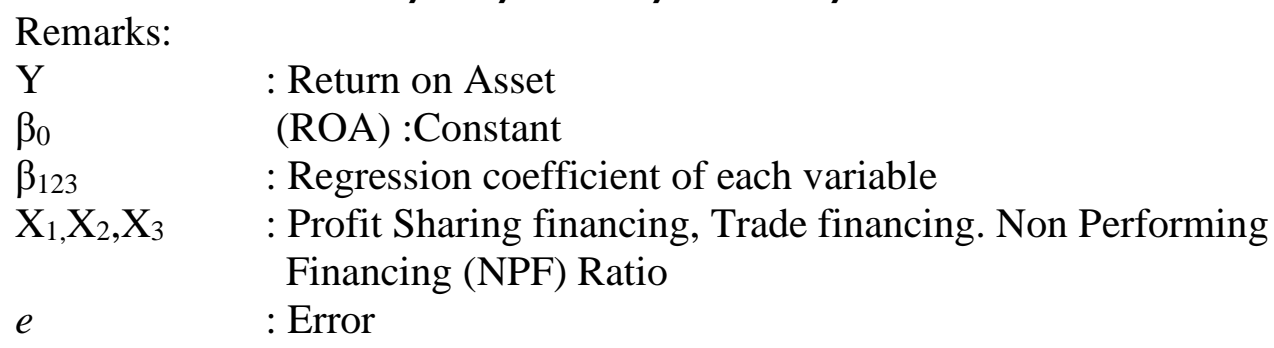


AFEBI Islamic Finance and Economic Review (AIFER)

Vol.03 No.01, June 2018

Hypothesis Test

1. Determination Coefficient Test $\left(\mathrm{R}^{2}\right)$

2. Partial Test (T test)

3. Simultant Test (F test)

\section{DISCUSSION}

\section{Stationarity Test Analysis}

A data is said to be stationary if the average value and the variants for several different lags have a continous constant value. For finding the data stationarity of profit sharing financing, trade financing, NPF ratio, and ROA, the Augmented Dickey-Fuller (ADF) test is implemented. The ADF test is implemented with the quarterly series data from 2013-2015. The following is the result of the stationarity data test using the ADF test in the Level Phase:

Table 2 Level Phase Stationarity Test

\section{ADF Statistical Test: $(\max \operatorname{lag}=11)$}

\begin{tabular}{|cllll|}
\hline \multicolumn{6}{c|}{ Stationarity Phase } \\
\hline Level & t-statistic $(a=5 \%)$ & Remarks \\
\hline $\mathbf{1}$ & Variable & ADF t-statistic & -2.896779 & Stationary \\
\hline $\mathbf{2}$ & Pby_Basil & -4.12306 & -2.896779 & Not Stationary \\
\hline $\mathbf{3}$ & Pby_Jb & -2.03303 & -2.896779 & Not Stationary \\
\hline $\mathbf{4}$ & NPF & -3.42135 & -2.896779 & Stationary \\
\hline & Source: Processed Data (eviews 9 output) & & \\
\hline
\end{tabular}

The ADF test result to the variables in the level phase shows that the profit sharing financing and trade financing variables are not stationary in the level phase. This is shown by the smaller ADF test statistical value than the critical value (for $a=5 \%$, as large as -2.896779). The research with non stationary data can produce a false regression (spurious regression). So, the test in the first difference phase needs to be implemented. With the note that if one of the variables were increased to the first difference phase, all variables have to be tested in the first difference phase.

Table 3 Difference Phase Stationarity Test

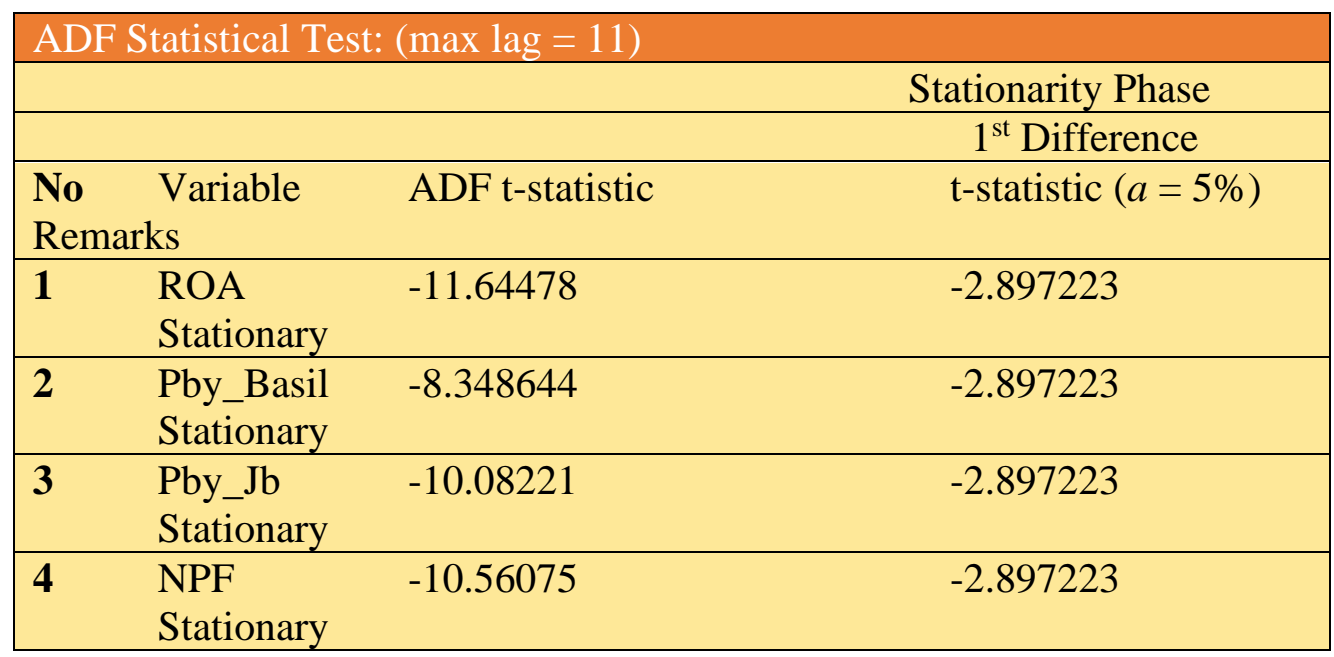

Source: Processed Data (eviews 9 output) 
The table above is the unit root test result in the first difference phase. From the table it can be seen that in the test in the first difference phase, all variæbles have a larger probability value than the critical value (for $a=5 \%$ as large as -2.896779). Therefore it can be interpreted that all variables in this research were already stationary in the same integration degree, so an analysis for the further phase can be done, which is the classic assumption test by using differentiated data in the stationarity test in the first difference phase.

\section{Classic Assumption Test Analysis}

Normality Test

The following is the normality test result table by using eviews 9 , which is:

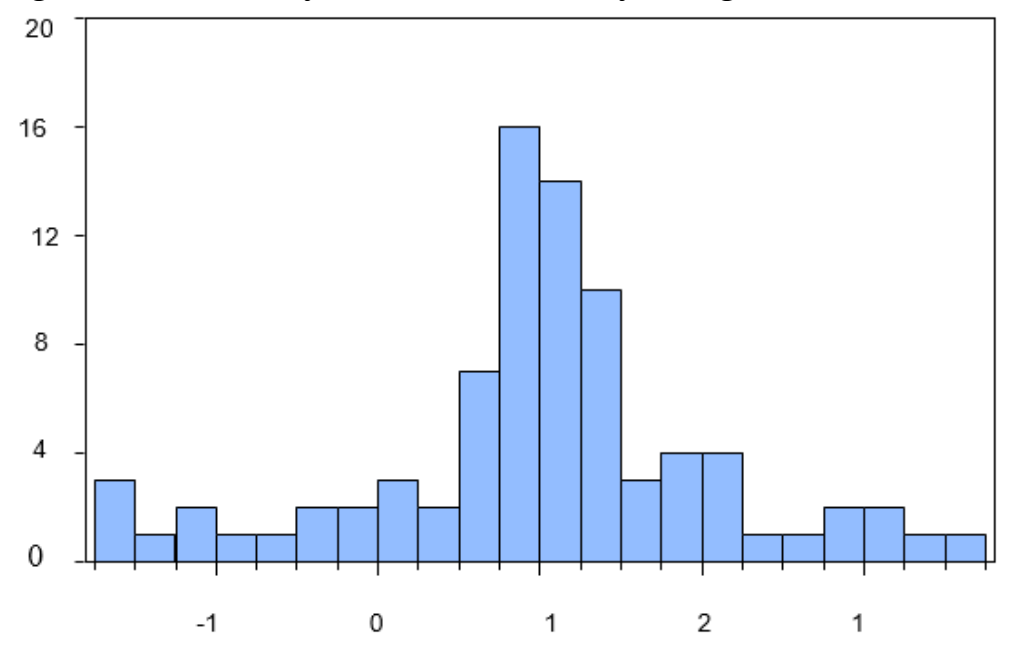

Figure 1 Normality Test

Series: Residuals

Sample 2.84

Observations 83y

Mean $-3.34 \mathrm{e}-18$

Median 0.073875

Maximum 2.606122

Minimum $-2.591747$

Std. Dev. 1.075285

Skewness $-0.266870$

Kurtosis

Jarque-Bera

2.400299

Probability

0.301149

Source: Processed data (eviews 9 output)

The normality test result is seen through the $J-B$ test and probability. Based on the result ithe $J-B$ test value is 2.4002 and the probability is 0.301149 , 
so with that result, the value can be interpreted as $>0.05$ (more than $5 \%$ ) so the data is distributed normally $\left(\mathrm{H}_{0}\right.$ accepted $\mathrm{H}_{\mathrm{a}}$ rejected).

\section{Multicolinearity Test}

The following is the table of the multicolinearity test by using eviews 9 , which is:

Table 4 Multicolinearity Test

\begin{tabular}{|ccc|}
\hline \multicolumn{3}{|c|}{ Correlation Matrix Between Variables } \\
\hline Variable & PBY_BASIL & PBY_JB \\
NPF & & -0.470055 \\
\hline PBY_BASIL & 1.000000 & \\
0.379628 & & 1.000000 \\
\hline PBY_JB & -0.470055 & - \\
0.354128 & & 0.354128 \\
\hline NPF & 0.379628 & \\
1.000000 & & \\
\hline
\end{tabular}

Source: Processed data (eviews 9 output)

For detecting multicolinearity, the correlation matrix is used. And the correlation matrix result is presented in table 4.3, so it can be analyzed that the correlation matrix result of every variable does not have a value of more than $0.90(<0.90)$. This means multicolinearity does not occur in the model $\left(\mathrm{H}_{0}\right.$ is accepted $\mathrm{H}_{\mathrm{a}}$ rejected). This means this research is free from the multicolinearity problem and worthy to be continued to the next phase.

\section{Heteroscedascity Test}

The following is the table of the heteroscedascity test result by using eviews 9, which is:

Table 5 Heteroscedascity Test

\begin{tabular}{lll}
\hline \hline F-statistic & 1.040257 & Prob. F (3.79) \\
0.3795 & & \\
Obs*R-squared & 3.154184 & Prob. Chi-Square (3) \\
0.3685 & & \\
Scaled explained SS & 3.771425 & Prob. Chi-Square (3) \\
0.2872 & & \\
\hline \hline
\end{tabular}

Source: Processed data (eviews 9 output)

The result of the heteroscedascity test using the white test. The Obs*RSquared is as large as 3.134184 (more than 5\%) so this means that heteroscedascity does not occur $\left(\mathrm{H}_{0}\right.$ is accepted $\mathrm{H}_{\mathrm{a}}$ rejected). This means that this research is free from the heteroscedascity problem and worthy to be continued to the next phase.

\section{Autocorrelation Test}

The following is the autocorrelation test result table by using eviews 9 which is: 
Table 6 Autocorrelation Test

\begin{tabular}{llll}
\hline \hline F-statistic & 4.369565 & Prob. F (2.77) & 0.0159 \\
Obs*R-squared & 8.459939 & Prob. Chi-Square (2) & 0.0146 \\
\hline \hline
\end{tabular}

Source: Processed data (eviews 9 output)

Based on the autocorrelation test result by using the Breusch-Godfrey test above, the Obs* R-Squared value is as large as 8.459939 and the Obs* Rsquared is $>0.05$ (more than $5 \%$ ) this means that autocorrelation does not occur $\left(\mathrm{H}_{0}\right.$ accepted $\mathrm{H}_{\mathrm{a}}$ rejected $)$. This means that this research is free of autocorrelation problems and worthy to continue to the next phase.

\section{Double Regression Analysis and Hypothesis Test Result}

In the model selection test, the model used in this research is the Common Effect Model (CEM), So the following equation result is obtained:

$$
\mathrm{Y}=0.053009 \mathrm{C}+(-1.119295) \mathrm{X} 1+(\mathbf{0 . 2 9 3 2 4 6}) \mathrm{X} 2+(-0.020162) \mathrm{X3}
$$

In the Common Effect Model equation the data is connected without observing the time and individual difference. So the behavior of data between Islamic Rural Banks are the same in several time periods, because of the permanent intercept.

Remarks:

$$
\begin{array}{ll}
\mathrm{Y} & \text { : Return On Asset (ROA) } \\
\mathrm{C} & : \text { Constant } \\
\mathrm{X}_{1}, \mathrm{X}_{2}, \mathrm{X}_{3} & \text { : Profit sharing financing, Trade financing, Non } \\
& \text { Performing Financing (NPF) Ratio }
\end{array}
$$

\section{Determination Coefficient $\left(\mathbf{R}^{2}\right)$}

The following is a presentation of the determination coefficient result for observing how far are the independent variables which are profit sharing financing $\left(\mathrm{X}_{1}\right)$, trade financing $\left(\mathrm{X}_{2}\right)$, and NPF in explaining the dependent variable which is Return on Asset (ROA). The determination test result by using eviews 9 can be seen in the table below:

Table 7 Determination Coefficient Test Result

\begin{tabular}{llll} 
R-squared & 0.103236 & Mean dependent var & 0.033506 \\
Adjusted R-squared & 0.066382 & S.D. dependent var & 1.078101 \\
S.E. of regression & 1.041703 & Akaike info criterion & 2.970141 \\
Sum squared resid & 79.21564 & Schwarz criterion & 3.091898 \\
Log likelihood & -110.3504 & Hannan-Quinn criter. & 3.018843 \\
F-statistic & 2.801257 & Durbin-Watson stat & 2.574277 \\
Prob (F-statistic) & 0.045848 & & \\
\hline
\end{tabular}


The counting result of the $\mathrm{R}^{2}$ value and Adjusted $\mathrm{R}$-squared based on table 7 were the numbers of 0.103236 or $10 \%$ and 0.066382 or $7 \%$. This is the relation of the independent variable to the dependent variable.

Value based, the Adjusted R-squared showed the variables of profit sharing financing, trade financing and the NPF ratio can explain $7 \%$ of the ROA variable. The other $93 \%$ are explained by other factors or other variables outside the model.

The Adjusted R-squared value is relatively low because the data used is a cross section where there are large variations between each observation. (Ghozali, 2013) Also, because the variable used is limited only from the financing element for explaining the ROA of Islamic Rural Banks.

\section{Partial Tests to Regression Coefficients (T tests)}

\section{a. Profit sharing financing variable test}

The profit sharing financing probability value of 0.0070 is less than the significant $5 \%(0.05)$ so $\mathrm{H}_{0}$ is rejected and $\mathrm{H}_{\mathrm{a}}$ is accepted, this means the profit sharing financing (independent variable) has a significant influence individually to the ROA (dependent variable) with a coefficient value of 1.119295 and a t-statistic value of -2.776849 .

The influence of profit sharing financing to ROA is negative in character $(\mathrm{t}$ statistic value of -2.776849) this value illustrates that the higher the profit sharing payment distribution to customers (Mudharabah and Musyarakah financing), the higher the chance of producing a low ROA value.

This can be caused by: first, customers that obtain financing (Mudharabah and Musyarakah) in certain periods do not all return the funds and provide the result in the period. Second, customer character. Not all customers are devout in returning funds according to the contract. Third, the theory correspondence that profit sharing financing is an investment activity where the profit sharing value is fluctuative (uncertain, high and low) depending on the condition of customers and the high risk of funds not returning.

The result of this research supports the research of Rochmanika (2012) and Yulianto (2014) which stated that profit sharing financing has a negative influence to ROA (object of Syariah Public Banks in Indonesia).

b. Trade financing variable test

The trade financing probability value of 0.293246 is more than the significant $5 \%(0.05)$ so $\mathrm{H}_{0}$ is accepted and $\mathrm{H}_{\mathrm{a}}$ is rejected, this means the trade financing (independent variable) does not have a significant influence individually to the ROA (dependent variable) with a coefficient value of 0.293246 and a t-statistic value of 0.321295 .

This is because the markup income that Islamic Rural Banks obtain are certain in value, and this is a trade contract, other than that, because the financing is distributed the value is the finished price (cost + markup) in corresponding with the theory.

The result of this research supports the research of Yulianto (2014) which stated that trade financing does not influence ROA (object of Syariah Public Banks in Indonesia).

c. Non Performing Financing (NPF) Ratio variable test

The NPF probability value of 0.5759 is more than the significant $5 \%(0.05)$ so $\mathrm{H}_{0}$ is accepted and $\mathrm{H}_{\mathrm{a}}$ is rejected, this means the NPF (independent variable) does not have a significant influence individually to the ROA 
(dependent variable) with a coefficient value of -0.020162 and a t-statistic value of 0.561968 .

This can be a cause of the NPF condition which is larger in one period and does not directly provide a profit decrease in the same period. When Islamic Rural Banks have a high number of problematic financing, they will first attempt to evaluate their performance with their policies while stopping their financing distribution activities until the NPF decreases or issue a financing efficiency policy.

\section{Simultaneous Regression Coefficient Test (F Test)}

The $\mathrm{F}$ test result showed that the F-statistic value is 0.045848 . This Fstatistic probability number is less than the significance level of $0.05(<5 \%)$ meaning that all independent variables (trade financing, profit sharing financing, and Non Performing Financing (NPF) Ratio) in this research have a simultaneous influence to Return on Asset (ROA).

\section{CONCLUSION}

Based on the research result done in this research a conclusion can be drawn, where what is patially obtained is the profit sharing financing variable (0.0070) which has an influence to ROA. This is because there are customers that do not fulfill the pact provisions or even skip the agreed pact. While the trade financing (0.7489) and NPF ratio (0.5759) do not have significant influences to ROA. While simultaneously the independent variables ( Profit sharing financing, trade financing, and NPF ratio) have significant influences to the ROA of Islamic Rural Banks in Central Java with an F-statistic probability value of 0.045848 .

The counting result of the $\mathrm{R}^{2}$ and Adjusted R-squared values are each 0.103236 or $10 \%$ and 0.066382 or $7 \%$ in numbers. This means that there is a relation between the independent and dependent variables.

Based on the Adjusted R-squared value, it shows that the variables of profit sharing financing, trade financing and NPF ratio are able to explain $7 \%$ of the ROA variable. The other $93 \%$ is explained by other factors or other variables outside the model.

The Adjusted R-squared value is relatively low because the data used is a cross section, where there is a large variation between each observation (Ghozali, 2013). Other than that, because the variable used is limited only from the financing element for explaining the ROA of Islamic Rural Banks.

The suggestion for further research is to add samples of other variables other than the variables in this research, lengthen the sample observation period, and also to use different measuring instruments or in different objects for finding whatever factors that influence the Return on Asset (ROA) value.

\section{References}

Agustiningrum, R. (2012). Pengaruh CAR, NPL, dan LDR terhadap Profitabilitas Terhadap Perusahaan Perbankan. Jurnal Fakultas Ekonomi Universitas Udayana, Bali, 885-902.

Altin, S. (2013). Analisis Kinerja Keuangan Bank BPRS Konvensional. Pekbis Jurnal, Volume 5, No 2.

BI. (1998). Undang-Undang No.10 Tahun 1998. Jakarta: 
www.bi.go.id. BI. (2008). Undang-Undang No. 21. Jakarta: www.bi.go.id.

BI, D. (1999). Surat Keputusan No. 32/36/KEP/DIR/1999. Jakarta: www.bi.go.id. Bratanovic, N. V. (2011). Analisis Risiko Perbankan. Jakarta: Salemba Empat. Djuwaini D., e. a. (2007). Pengantar Fiqh Muamalah. Bogor: LPPM Tazkia. Fahmi, I. (2014). Analisi Laporan Keuangan. Bandung: Alfabeta.

Fatimah, S. (2013). Pengaruh Rentabilitas, Efesiensi, dan Likuiditas Terhadap Kecukupan Modan Bank Umum Syariah. BCA Finance, 42-58.

FE-UMJ, L. (2011). Modul Statistika. Ciputat: Laboratorium Statistika FEUMJ. Ghofur, A. (2016). Analisis terhadap Manajemen Dana Mudharabah dalam

Perbankan Syariah. Jurnal at-Taqaddum, Vol 8 No. 2, November 2016, 129149.

Ghozali, I. (2013). Analisis Mutivariat dan Ekonometrika. Semarang: Badan Penerbit UNDIP Semarang.

Hadiyati, P. (2013). Pengaruh Non Performing Financing, Pembiayaan Mudharabah, Pembiayaan Musyarakah pada Bank Muamalat Indonesia. e-journal Manajemen Bisnis, 1(1), 48-61.

Harinaldi. (2005). Prinsip-Prinsip Statistik untuk Teknik dan Sains. Jakarta: Penerbit Erlangga.

Hendrayanti, S., \& Muharam, H. (2013). Analisis Pengaruh Faktor Internal dan Eksternal Terhadap Profitabilitas Perbankan (Studi pada Bank Umum di Indonesia Periode. Volum 2., Nomor 3, Tahun 2013, Halaman 1-15.

Hery, S. M. (2015). Analisis Laporan Keuangan Pendekatan Rasio Keuangan. JAKARTA: CAPS (Center For Academic Publishing Service).

Ifham, A. (2016). Strategi Penanganan Pembiayaan Bermasalah. Depok: Heryana Media.

Iqbal, M. (2010). Mendirikan Lembaga Keuangan LKM. Jakarta: PT Elex Media Komputindo.

Irshad, S. G. (2011). Factors Affecting Bank Profitability in Pakistan. The Romanian Economic Journal year XIV, No 39 March 2011.

Jumingan. (2011). Analisi Laporan Keuangan. Jakarta: Media Grafika.

Kasmir. (2014). Manajemen Perbankan (edisi revisi). Jakarta: PT Rajagrafindo Persada.

Linawati, L. (2011). Economi Value added Ukuran Keberhasilan Kinerja Keuangan Manajemen Perusahaan. Jurnal Akuntansi dan Keuangan Universitas Negeri Semarang, No.1, Desember, 1, 2011, 28-30.

Mawardi, W. (2005). Analisis Faktor-Faktor yang Mempengaruhi Kinerja Keuangan Bank Umum di Indonesia (Studi Kasus Pada Bank Umum 
THE INFLUENCE OF PROFIT SHARING, TRADE FINANCING, AND THE NON PERFORMING FINANCING RATIO TO THE RETURN ON ASSET OF ISLAMIC RURAL BANKS IN CENTRAL JAVA (2013-2015 PERIOD)

Dengan Total Asset Kurang Dari 1 Triliun). Jurnal Bisnis Strategi, 85.

MUI, D. (2000). Fatwa DSN MUI No. 4 tentang Pembiayaan Murabahah. Jakarta: www.dsnmui.or.id.

MUI, D. (2000). Fatwa DSN MUI No. 8 tentang Pembiayaan Musyarakah. Jakarta: www.dsnmui.or.id.

MUI, D. (2000). Fatwa DSN MUI No.7 tentang Pembiayaan Mudharabah. Jakarta: www.dsnmui.or.id.

OJK. (2014). POJK No.16/POKJ.03/2014 perihal Penilaian Kualitas Aset BUS dan UUS. Jakarta: www.ojk.go.id.

OJK. (2016, July 1). Bank Perkreditan Rakyat Syariah. Retrieved Oktober 20, 2016, from www.ojk.go.id: http://www.ojk.go.id/bank-perkreditan-rakyat

OJK. (2016). Laporan Profil Industri Perbankan Triwulan III. Jakarta: OJK. Perwira, B. B. (n.d.). Retrieved Tuesday January , 2016, from http://www.bprsbmp.com.

Rochmatika, A. F. (2012). Pengaruh Pembiayaan Jual Beli, Pembiayaan Bagi Hasil, dan Rasio Non Performing Financing terhadap Profitabilitas Bank Umum Syariah di Indonesia. Fakultas Ekonomi dan Bisnis Universitas Brawijaya.

Setiawan, H. A.-S. (2015). Analisis Pengaruh Suku Bunga SBI, Uang Beredar, Inflasi dan Nilai Tukar terhadapIndeks Harga Saham Jakarta Islamic Index (JII) Peiode 2009-2014. Jurnal Ekonomi dan Perbankan Syariah Vol.3,, No,2, Oktober 2015, ISSN (Cet):2355-1755, 26-46.

Sudarsono, H. (2012). Bank dan Lembaga Keuangan Syariah. Yogyakarta: EKONISIA Yogyakarta.

Sugiyono. (2016). Metode Penelitian Kombinasi. Bandung: Alfabeta.

Sumitro, W. (2004). Asas Asas Perbankan Islam dan Lembaga-Lembaga Terkait . Jakarta: Raja Grafindo Persada.

Suprapto, F. K. (2015). Faktor-Faktor yang Mempengaruhi Profitabilitas Bank Muamalat Indonesia. Jurnal Ekonomi dan Perbankan Syariah Vol.4 No.2 Oktober 2015, ISSN (Cet): 2355-1755, 2-24.

Suryani. (2011). Analisis Pengaruh Financing Deposit Ratio (FDR) Terhadap Profitabilitas Perbankan syariah di Indonesia. Volume 11, nomor 1 .

Suryani. (2011). Analisis Pengaruh Financing to Depost Ratio (FDR) Terhadap Profitabilitas Perbankan Syraiah di Indonesia. Walisongo volume 19 Nomor 1.

Suryani, H. (2015). Metode Riset Kuantitatif Teori dan Aplikasi pada Penelitian Bidang Manajemen dan Ekonomi Islam. Jakarta: Prenadamedia Group.

Wardiah, M. L. (2013). Dasar-Dasar Perbankan. Bandung: CV. Pustaka Setia. Warsono, S. (2008). Akuntansi Pengantar 1 Berbasis Matematika. 
AFEBI Islamic Finance and Economic Review (AIFER)

Vol.03 No.01, June 2018

Asgard Chapter.

Wibowo. (2013). Analisis Pengaruh Suku Bunga, Inflasi, CAR, NOPO, NPF Terhadap Profitabilitas Bank syariah. Jurnal Manajemen, Volum 2, Nimie 22, 2013,, 4.

Widarjono, A. (2013). Ekonometrika Pengantar dan Aplikasinya disertai Panduan Eviews. Yogyakarta: UPP STIM YKPN.

Winarno, W. W. (2011). Analisis Ekonometrika dan Statistik dengan Eviews. Yogyakarta: Unit Penerbit dan Percetakan STIM YKPN .

Yulianto, S. R. (2014). Pengaruh Pembiayaan Bagi Hasil, Pembiayaan Jual Beli, Financing to Deposit Ratio (FDR) dan Non Performing Financing (NPF) terhadap Profitabilitas Bank Umum Syariah Di Indonesia. Accounting Analysis Journal, 466-474.

Administrator. (2011).http://zonaekis.com/bprs-insan-madani-akuisisi-bprkleco-joyo-solo. Retrieved January 12, 2017, from Zona Ekis: http://zonaekis.com

Administrator. (2014).http://www.ojk.go.id/id/kanal/perbankan/data-danstatistik/laporan-keuangan-perbankan/Default.aspx. Retrieved November 11, 2016, from OJK: http://www.ojk.go.id

Administrator. (2015). http://www.bprsarthasuryabarokah.com/profilperusahaan/. Retrieved January 12,2017 from BPRS Artha Surya Barokah: http://www.bprsarthasuryabarokah.com

Administrator. (2015). http://www.bprsbmp.com/p/daftar-isi.html. Retrieved January 12, 2017, from BPRS Buana Mitra Perwira: http://www.bprsbmp.com

Administrator. (2017). http://bprgunungslamet.com/index.php/2017-04-26-0245-45. Retrieved April 30, 2017 from BPRS Gunung

Slamet: http://bprgunungslamet.com

Administrator. (n.d.). http://banksyariahku.com/tentag-suriyah.html. Retrieved January 12, 2017, from Bank Syariah Suriyah: http://www.banksyariahku.com

Administrator. (n.d.). http://elc.stain-pekalongan.ac.id/230/10/BAB\%203.pdf. Retrieved January 12, 2017 from the Repository of IAIN Pekalongan: http://elc.stain-pekalongan.ac.id/ 